\title{
Safety considerations of biosimilars
}

\section{Ross McKinnon}

Associate Dean of research

School of Medicine

Flinders Centre for

Innovation in Cancer

Flinders University

\section{Michael Ward}

Discipline leader of

pharmacy education

School of Pharmacy and

Medical Sciences

University of South

Australia

Adelaide

\section{Keywords}

bioequivalence, biologic drug, biosimilar drug, generic drug, monoclonal antibody

Aust Prescr 2016;39:188-9 http://dx.doi.org/10.18773/ austprescr.2016.084
Over recent decades, some of the most important therapeutic advances have involved the use of biologic drugs. These are typically large complex molecules derived from a biological source, such as yeast or cell culture, rather than a chemical source. Examples of biologic drugs include monoclonal antibodies like infliximab and ipilimumab, and smaller proteins such as insulin and erythropoietin.

Patents on many originator biologic drugs are coming to an end allowing other companies to produce them. This is likely to cause significant price reductions in much the same way as generic manufacturers reduce the cost of small-molecule drugs. However, because of the complexity of biologic drugs, the traditional understanding of bioequivalence* with generic drugs cannot be directly applied.' For this reason, off-patent biologic drugs produced by alternative manufacturers are referred to as biosimilars or 'similar biological medicinal products' rather than generic medicines. They are subject to different regulatory considerations ${ }^{2}$ compared to generic small-molecule drugs because their complexity and the way they are produced has the potential to result in variability in the final product between manufacturers and batches.

One of the most significant safety concerns with biosimilars is the potential risk of immune-based adverse reactions. Because of their molecular size, biologics can directly induce anti-drug antibodies which may have significant consequences for both safety and efficacy. This was highlighted by experience with erythropoietin over a decade ago when changes in manufacturing appeared to make the product more immunogenic. This significantly increased the risk of treatment-induced pure red cell aplasia and resulted in high fatality rates and rendered other patients dependent on blood transfusions. ${ }^{3}$ More recently, Thailand experienced a significant number of cases of pure red cell aplasia following the introduction of 'bio-copy' erythropoietin products. ${ }^{4}$ At the time in Thailand, these products were assessed using the same regulatory framework as for generic small-molecule drugs, which focuses on showing bioequivalence. This is drastically different from the

\footnotetext{
* Bioequivalence is shown when, after administration, two products produce such similar plasma concentrations of the active ingredient that their clinical effects can be expected to be essentially the same.
}

current regulatory pathways for biosimilar drugs in Australia (and internationally) which demand clinical data showing that the biosimilar is equally as safe and efficacious as the originator biologic drug.

While the biosimilar regulatory framework attempts to address the concerns related to immunogenicity, potential uncertainty remains. In a recent clinical trial of a biosimilar etanercept, the incidence of patients with anti-drug antibodies was lower with the biosimilar (0.7\%) than with the reference drug (13.1\%). ${ }^{5}$ The significance of this finding has been debated, particularly the transient nature and limited duration of anti-drug antibody positivity observed in these patients. This example highlights the complexities in this area including the technical challenges associated with detecting and quantifying anti-drug antibodies, the timing of patient assessments compared to the original studies of the reference product, and the assessment of the clinical impact of anti-drug antibodies.

In an attempt to balance the safety concerns of biosimilars against an overly onerous and costly clinical development pathway, clinical data are not required for approval of every potential indication. ${ }^{2}$ Registration of the biosimilar for some indications might be based on clinical evidence of comparable clinical efficacy and safety in another indication. This potentially increases the uncertainty of the comparability of the biosimilar with the reference product.

It is possible that there are differences between conditions on the basis of the indication or the molecule. For example, the use of concurrent drugs such as an immunosuppressant often varies between indications, with the potential for differences in the risk of the formation of anti-drug antibodies. Likewise, the drug's mechanism of action may differ depending on the indication and it is possible that small differences in physicochemical characteristics could result in differences in clinical outcomes.

The extrapolation of indication has been recently illustrated with the approval of a biosimilar infliximab for inflammatory bowel disease following initial studies conducted in rheumatoid arthritis and ankylosing spondylitis. Although this creates a degree of uncertainty, surveys of gastroenterologists suggest that initial reservations subsided once they gained experience with the biosimilar. ${ }^{6,7}$ Current data 
suggest that the biosimilar infliximab is generally well tolerated and efficacious in inflammatory bowel disease in patients who have not previously received biological therapy. ${ }^{8,9}$

While clinical trials may show comparable safety and efficacy, the trial design may not look at switching between the reference product and the biosimilar. Open-label extension studies of phase III trials with the biosimilar infliximab, and the NOR-SWITCH study, a double-blind study assessing the safety and efficacy from originator to biosimilar infliximab, are providing reassuring data of the outcomes associated with switching therapy. ${ }^{8,10,11}$ However, data relating to switching generally remain limited.

Administration of biologics is more complex than with small-molecule drugs. Switching or substituting a bioequivalent oral generic drug is often simple and may only require patient education about the difference in its appearance. However, because biologics are administered parentally, devices are required. Device design is proprietary so biosimilars will have a different device not only in appearance but also potentially in function. This could cause problems with safety. For instance with biosimilar insulin, many patients use pen devices but not all pens are compatible with the cartridges produced by the different biosimilar manufacturers. Although manageable through education, care needs to be taken to ensure that patients switching between products do not become confused.

Because of the uncertainties associated with the use of biosimilars, pharmacovigilance is important. Fundamental to this is accurate documentation and reporting of the specific products for each patient. At present naming conventions for biosimilars are still being established. Traceability may prove difficult in patients who undergo multiple switches or substitutions between the reference product and the biosimilar. ${ }^{12}$

In comparison with traditional small-molecule drugs, biosimilars have unique safety considerations. Owing to the diversity in their structural complexity and indications, safety will need to be considered on a drug-by-drug basis. Early experience indicates that once biosimilars become available, initial safety concerns will decrease. However, there remains a need for appropriate pharmacovigilance which considers the unique properties of these drugs. $\varangle$

Ross McKinnon and Michael Ward have both provided educational presentations sponsored by AbbVie and Sanofi Aventis. Ross McKinnon has participated in Advisory Board activities for AbbVie.

\section{REFERENCES}

1. McKinnon RA, Lu CY. Biosimilars are not (bio)generics. Aust Prescr 2009;32:146-7. http://dx.doi.org/10.18773/ austprescr.2009.072

2. Australian Government Department of Health. Therapeutic Goods Administration. Regulation of biosimilar medicines. Version 2.0, December 2015. www.tga.gov.au/publication/ evaluation-biosimilars [cited 2016 Nov 1]

3. Kuhlmann M, Marre M. Lessons learned from biosimilar epoetins and insulins. Br J Diabetes Vasc Dis 2010;10:90-7. http://dx.doi.org/10.1177/1474651409355454

4. Praditpornsilpa K, Tiranathanagul K, Kupatawintu P, Jootar S, Intragumtornchai T, Tungsanga K, et al. Biosimilar recombinant human erythropoietin induces the production of neutralizing antibodies. Kidney Int 2011;80:88-92. http://dx.doi.org/10.1038/ki.2011.68

5. Emery P, Vencovský J, Sylwestrzak A, Leszczyński P, Porawska W, Baranauskaite A, et al. A phase III randomised, double-blind, parallel-group study comparing SB4 with etanercept reference product in patients with active rheumatoid arthritis despite methotrexate therapy. Ann Rheum Dis 2015 Jul 6. [Epub ahead of print] http://dx.doi.org/10.1136/annrheumdis-2015-207588

6. Danese S, Fiorino G, Michetti P. Viewpoint: knowledge and viewpoints on biosimilar monoclonal antibodies among members of the European Crohn's and Colitis Organization. J Crohns Colitis 2014;8:1548-50. http://dx.doi.org/10.1016/ j.crohns.2014.06.007

7. Danese S, Fiorino G, Michetti P. Changes in biosimilar knowledge among European Crohn's Colitis Organization (ECCO) members: an updated survey. J Crohns Colitis 2016 Apr 25. [Epub ahead of print] http://dx.doi.org/ 10.1093/ecco-jcc/jjw090
8. Yoo DH, Prodanovic N, Jaworski J, Miranda P, Ramiterre E, Lanzon A, et al. Efficacy and safety of CT-P13 (biosimilar infliximab) in patients with rheumatoid arthritis: comparison between switching from reference infliximab to CT-P13 and continuing CT-P13 in the PLANETRA extension study. Ann Rheum Dis 2016 Apr 29. [Epub ahead of print] http://dx.doi.org/10.1136/annrheumdis-2015-208786

9. Jahnsen J. Clinical experience with infliximab biosimilar Remsima (CT-P13) in inflammatory bowel disease patients. Therap Adv Gastroenterol 2016;9:322-9. http://dx.doi.org/ 10.1177/1756283X16636764

10. Park W, Yoo DH, Miranda P, Brzosko M, Wiland P, Gutierrez-Ureña S, et al. Efficacy and safety of switching from reference infliximab to CT-P13 compared with maintenance of CT-P13 in ankylosing spondylitis: 102-week data from the PLANETAS extension study. Ann Rheum Dis 2016 Apr 26. [Epub ahead of print] http://dx.doi.org/10.1136/ annrheumdis-2015-208783

11. GaBI Online - Generics and Biosimilars Initiative. NOR-SWITCH study finds biosimilar infliximab not inferior to originator. [Posted 21 October 2016] Mol, Belgium: Pro Pharma Communications International. www.gabionline.net/Biosimilars/Research/NOR-SWITCHstudy-finds-biosimilar-infliximab-not-inferior-to-originator

12. Stergiopoulos S, Brown CA, Grampp G, Felix T, Getz KA. Identifying and quantifying the accuracy of product name attribution of US-sourced adverse event reports in MedWatch of somatropins and insulins. Ther Innov Regul Sci 2015;49:706-16. http://dx.doi.org/10.1177/2168479015578156

\section{FURTHER READING}

Council of Australian Therapeutic Advisory Groups. Overseeing biosimilar use: guiding principles for the governance of biologica and biosimilar medicines in Australian hospitals. Version 2 September 2016. Sydney: CATAG; 2016.
McLachlan AJ, Ramzan I, Milne RW. Frequently asked questions about generic medicines. Aust Prescr 2007:30:41-3. http://dx.doi.org/10.18773/austprescr.2007.021 